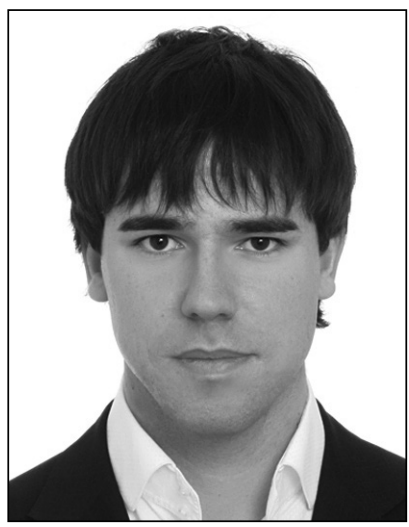

\author{
Олексій Олександрович Борбунюк, \\ аспірант \\ Начіональний юридичний університет \\ імені Ярослава Мудрого, \\ м. Харків
}

\title{
YAK 342.924
}

\section{ЩОАО ВИЗНАЧЕННЯ НОРМАТИВНО-ПРАВОВОГО АКТА В ААМIHICТРАТИВНОМУ ПРАВІ}

Розкрито понятійно-категоріальний апарат поняття нормативно-правового акта, основні теоретико-методологічні підходи до проблеми його визначення. Виділено загальні ознаки нормативно-правового акта як письмового документа, що містить норми-правила поведінки загального спрямування.

Ключові слова: нормативно-правовий акт, теорія нормативно-правового акта, визначення нормативно-правового акта, адміністративний акт, правовий акт.

Одним із шляхів реалізації правової реформи в світлі нормотворчої діяльності органів державної влади в Україні є запровадження одноманітного підходу щодо визначення такого поняття, як нормативно-правовий акт (далі - НПА).

У теорії права у загальному вигляді гетерономний (від грец. гетерос інший, номос - закон, тобто такий, що встановлений іншими законами) правовий акт визначено як письмовий документ, який містить правовий текст загального змісту [1, с. 649]. Свого часу правову природу НПА в теоpiї адміністративного права досліджували В. Б. Авер'янов, С. С. Алексєєв, С. А. Антоненко, Д. М. Бахрах, Т. О. Гуржій, П. І. Кононов, О. В. Кузьменко, Р. С. Мельник, О. Ф. Ноздрачев, Д. В. Осінцев, І. Д. Пастух, В. П. Тимощук, С. В. Тихомиров та ін. Утім, наукові праці зазначених вчених висвітлюють лише окремі аспекти поняття НПА. Нагальною потребою часу є розробка доктрин з окремих складових адміністративного права, у тому числі й концептуальних засад НПА [2, с. 126]. Тому вважаємо актуальним проведення наукової розвідки зазначеного питання шляхом узагальнення наукових поглядів на правову природу НПА та досвіду законотворення окремих країн з огляду на можливість його запровадження в Україні, що, власне, й обумовило мету цієї статті. 
Поняття НПА залишається дискусійним у наукових колах і невирішеним на законодавчому рівні. Як джерело державної політики, НПА закладають ідеологічну, політичну та правову основу державної діяльності. У цьому аспекті важливе значення мають завдання правової реформи, спрямовані на зниження невизначеності правових постанов та обмеження необгрунтованої свободи розсуду правозастосовців. Убачається, що теперішній розвиток адміністративного права та державного управління потребує якісно нового підходу до його регулювання з боку держави. Так, деякі вчені країн СНД, вирішуючи аналогічні питання, стверджують, що наразі ми переживаємо нелегкий час, що проявляється у постійних несистемних змінах та доповненнях нормативно-правових актів, появі нових галузей права [3, с. 22], і слушно акцентують увагу на тому, що подолання цих проблем потребує врегулювання перш за все самого правотворчого процесу шляхом видання «Закону про закони».

У теорії адміністративного права запропоновано визначення НПА через такі категорії, як документ (Д. В. Осінцев, О. Р. Дашковська, М. В. Цвік, О. В. Петришин, О. Ф. Скакун, О. В. Зайчук, С. А. Антоненко, Ю. М. Оборотов, І. В. Панова, О. В. Горун, О. В. Нестеров, С. С. Алексєєв, В. Я. Малиновський), акт (Ю. М. Старілов, Г. Федоров, Р. С. Мельник, А. Ф. Ноздрачов), рішення (П. І. Кононов, Ю. І. Мігачов, С. В. Тихомиров, Т. О. Гуржій), дія (О.І.Харитонова), припис (Д. В. Лученко), волевиявлення (А. М. Миронов). Ю. М. Старилов звертає увагу також на традиційний погляд на НПА як форму управлінської діяльності (форму державного управління) [4, с. 50]. Аналіз зазначених підходів до визначення НПА свідчить, що вчені надають перевагу окремим рисам цього феномена. Між тим, дослідження його суті потребує комплексного підходу й зосередження уваги на його змістовному наповненні.

Р. Ф. Васильєв одним із перших звернув увагу на комплексний характер досліджуваного нами явища $[5$, с. 88]. Значні розбіжності спостерігаються при порівнянні характеристик актів управління, загальних властивостей та їх ознак. Автор слушно зазначає, посилаючись на класика: «Дефініцій може бути багато, адже багато сторін в предметах...» [Цит. за: 5, с. 88]. Існування різних визначень НПА виражає складність останнього. Складні поняття розкриваються лише за допомогою різних характеристик. НПА, як комплексне явище, потребує висвітлення максимально можливої сукупності характеристик. Оскільки НПА є різновидом акта управління, важливим є зв язок, об єктивно існуючий між ними. Для з ясування поняття нормативно-правового акта важливим є визначення акта управління. Як зазначає Р. Ф. Васильєв, в юридичній літературі радянського періоду поняття актів управління визначалось по-різному: через форму діяльності, дії, волевиявлення, як приписи, документи, офіційні рішення, результат волевиявлення, як загальне поняття актів державних органів та ін. Акти управління називають: формою управління; однією із форм діяльності державних службовців; результатом управлінської діяльності; як вираження управлінських дій правовими формами реалізації компетенції державних органів; як результат правотворчої форми діяльності; як особливу 
форму управління; як односторонні владні веління; результат управлінської діяльності; як форму певного змісту тощо [5, с. 88]. Безперечним є той факт, що соціальна природа поняття публічного управління зумовлена, насамперед, одночасною належністю актів до правових та управлінських явищ. Зрозуміло, що неможливо розглядати публічне управління у відриві від адміністративного права, так само, як і останнє неможливо розглядати без його регулюючих, управлінських функцій. Автор розглядає акти управління як владні волевиявлення державних органів і інших суб єктів державного управління, які встановлюють, застосовують, змінюють, відміняють правові норми і змінюють сферу їх дії, які здійснюються в установленому порядку на основі і на виконання законів у процесі виконання функцій державного управління і діють у формі усних велінь або документів, що містять відповідні веління (приписи) [5, с. 140].

Не можна не погодитись 3 тезою Ю. М. Старілова, що правовий акт управління (адміністративний акт) - це складне, комплексне правове явище, хоча в визначеннях останнього, що надані різними авторами, багато спільного [4, с. 54]. Разом з тим, на думку вченого, існує два фактори, які розтлумачують використання зазначених категорій при визначенні акта управління: 1) управлінська сутність і природа правового акта та 2) правовий характер акта управління [4, с. 54]. Важливим є погляд щодо дуалізму природи адміністративних актів, що в свою чергу визначає їх функції, характер зв`язків і відносин, які складаються як в процесі їх підготовки, так і на етапі їх підготовки, виконання та контролю їх виконання. Зазначені особливості правової природи є анологічними і для НПА [4, с. 55].

У деяких дослідників цілком слушно виникає побоювання, чи не створює такий «вільний підхід» до тлумачення поняття «нормативно-правовий акт» та до співзвучних із ним термінів загроз для якості правового регулювання суспільних відносин [6, с. 275].

Зазначимо, що процес правотворчості як загальне поняття складається, у свою чергу, з законотворчого та нормотворчого процесів. Результатом останнього є видання (прийняття) нормативних актів. Їх особливістю є визначена законом або іншими актами форма, особливий порядок видання (прийняття) та суб`єкт, якому надане таке право, та інші, встановлені законом особливості.

Отже, як слушно зазначають науковці, акти управління мають дві функціональні особливості: правову і управлінську [7, с. 216]. Крім того, без правових актів не може бути публічного управління як такого, водночас без них правова система держави втрачає своє регулююче призначення у сфері дій публічної адміністрації. Таким чином, НПА в державному управлінні також має управлінську і правову функціональну особливість.

Т. О. Гуржій звертає увагу на існування декількох підходів до тлумачення етимології слова «акт», вказуючи, що одні вчені вважають, що зазначене слово походить від латинського actus - дія, вчинок, інші в основу своїх міркувань покладають його походження від латинського слова - actum (документ), треті керуються тим, що вітчизняні словники визначають слово «акт» похідним від 
обох зазначених латинських термінів [8, с. 119]. Так, відповідно до Універсального словника української мови слово «акт» походить від латинського actus - дія і позначає одиничний вияв якої-небудь діяльності; дії; вчинку, а також закон, указ, постанову, які видають уряд, громадська організація або посадова особа [9, с. 21].

У наш час досить часто в юридичній науці як синоніми актам державного управління використовують й інші назви - правові акти управління, адміністративні акти, акти державної адміністрації [10, с. 251]. На нашу думку, вдалим $€$ визначення акта державного управління як офіційного припису (документа вставка авт.), який заснований на законі, прийнятого (виданого - вставка авт.) суб єктом управління у порядку одностороннього волевиявлення в межах його компетенції з додержанням встановленої форми та процедури, спрямованого на досягнення встановленого законодавством результату [11, с. 156].

Конституція України оперує такими поняттями, як нормативно-правовий акт; рішення органів державної влади, органів місцевого самоврядування, посадових і службових осіб (див. зокрема статті 8, 55, 57 Конституції України), а також установлює деякі вимоги щодо них. Кодекс адміністративного судочинства України у ст. 2 застосовує поняття рішення суб єктів владних повноважень; у ст. 171 - НПА; у ст. 171-1 - актів, дій; у ст. 174 - рішення, дії. Постає цілком очевидне питання визначення зазначеного поняття у концентрованому вигляді.

Для нашого дослідження певний науковий інтерес становлять положення Адміністративного кодексу УРСР від 12 жовтня 1927 р., який містить поняття адміністративного акта [12] і визначає, що загальними адміністративними актами є: 1) інструкції й обіжники та 2) обов'язкові постанови. Змістом першого є загальні пояснення підлеглим урядовим особам та установам того, як запроваджувати в життя той чи інший закон або постанову радянської влади, або пояснення їх змісту, а також викладення додаткових правил до законів і постанов у межах, ними встановлених. Щодо обов язкових постанов, то відповідно до артикулу 28 округовим і районним виконавчим комітетам, їх президіям і міським та селищним радам надавалось право, в обсягу їх компетенції (арт. 49) і у межах їх території, на виконання чинного законодавства видавати обов'язкові постанови, тобто такі, що оголошуються до загального відома й які встановлюють: а) будь-які обов'язки для всієї людності даної території або їх окремих груп; б) відповідальність за зламання або невиконання цих обов'язків адміністративним порядком. Крім того, вказано, що постанови, що їх ухвалили зазначені органи на своїх засіданнях і які не відповідають ознакам, вказаним вище, не можна вважати за «обов’язкові постанови».

Подальший науковий інтерес до розвитку інституту НПА в Україні пов'язаний із Розпорядженням Голови Верховної Ради України від 31 жовтня 1994 р., згідно з яким ученим Інституту законодавства Верховної Ради України було доручено розробити проект Закону України «Про закони і законодавчу діяльність в Україні». Одночасно іншою групою вчених-правознавців підготовлено проект Закону України «Про нормативні правові акти». Загалом, починаючи 
з 1994 р., у Верховній Раді України було зареєстровано вісім законопроектів із зазначених питань, проте жоден із цих проектів так і не був прийнятий парламентом України [13, с. 39]. Так, за останнім законопроектом «Про нормативно-правові акти» від 1 грудня 2010 р. вченими запропоновано розглядати НПА як офіційний документ, прийнятий (виданий) уповноваженим на це суб'єктом у визначених законом формі та порядку, що містить норми права (ст. 1 проекту) [14]. Однак зазначена спроба закріпити легальне визначення НПА на законодавчому рівні не реалізована парламентом; законопроект очікує на друге читання.

Автори проектів Адміністративного процесуального кодексу 2008 р. та 2012 р. пропонують під адміністративним актом розуміти рішення, правовий акт, документ, відмітку в документі [15]. Автори законопроектів одностайні у тому, що такий акт є актом індивідуальної дії, прийнятим адміністративним органом за результатами розгляду адміністративної справи відповідно до цього Кодексу, спрямований на набуття, зміну чи припинення прав та обов'язків фізичної або юридичної особи (осіб) (ч. 4 ст. 2).

Стаття 52 Закону України «Про Кабінет Міністрів України» встановлює, що КМУ на основі та на виконання Конституції і законів України, актів Президента України видає обов'язкові для виконання акти - постанови і розпорядження [16]. Акти нормативного характеру видаються у формі постанов, а акти 3 організаційно-розпорядчих та інших поточних питань - у формі розпоряджень. Розвиваючи ці положення, Регламент КМУ (розд. 4 гл. 1 § 29) встановлює, що акти уряду нормативного характеру у формі постанов видаються з питань затвердження положення, статуту, порядку, регламенту, правил, методики та в інших випадках, коли суспільні відносини потребують нормативно-правового врегулювання, а також затвердження, прийняття міжнародного договору або приєднання до нього [17].

Аналогічний підхід міститься і в ч. 1 ст. 15 Закону України «Про центральні органи виконавчої влади» (далі - ЦОВВ): міністерство у межах своїх повноважень видає накази, які підписує міністр [18]. Крім того, відповідно до ч. 1 ст. 23 зазначеного Закону інші ЦОВВ у межах своїх повноважень також видають накази організаційно-розпорядчого характеру, організовують та контролюють їх виконання.

У пункті 1.4 наказу Міністерства юстиції України «Про вдосконалення порядку державної реєстрації нормативно-правових актів у міністерстві юстиції України та скасування рішення про державну реєстрацію нормативно-правових актів» зазначено, що НПА є офіційним письмовим документом, прийнятим уповноваженим на це суб'єктом нормотворення у визначеній законодавством формі та за встановленою законодавством процедурою, спрямований на регулювання суспільних відносин, що містить норми права, має неперсоніфікований характер і розрахований на неодноразове застосування [19].

Цікавим є внесок судової практики у вирішення досліджуваного питання. Так, Конституційний Суд України в пункті 4 рішення від 16 квітня 2009 р., № 7-рп/2009 у справі за конституційним поданням Харківської міської ради зазначив, що до нормативних належать акти, які встановлюють, змінюють чи 
припиняють норми права, мають локальний характер, розраховані на широке коло осіб та застосовуються неодноразово [20]. Зазначена позиція знайшла відображення і в попередніх рішеннях Конституційного Суду України (рішення від 27 грудня 2001 р., № 20-рп/2001 у справі про Укази Президії Верховної Ради України щодо Компартії України (абзац перший пункту 6 мотивувальної частини) [21], від 23 червня 1997 р. № 2-зп у справі про акти органів Верховної Ради України (абзац четвертий пункту 1 мотивувальної частини)) [22].

Порушене питання знайшло відображення і у постанові Пленуму Вищого Адміністративного суду України «Про окремі питання юрисдикції адміністративних судів» [23]. Відповідно до п. 1 ч. 2 ст. 17 , ч. 1 ст. 171 та ч. 1 ст. 171.1 Кодексу адміністративного судочинства України до юрисдикції адміністративних судів належить вирішення питання щодо законності (крім конституційності) підзаконних правових актів Верховної Ради України, Президента України, КМУ, Верховної Ради АРК, а також законності та відповідності правовим актам вищої юридичної сили правових актів міністерств, інших центральних органів виконавчої влади, Ради міністрів АРК, місцевих державних адміністрацій, органів місцевого самоврядування, інших суб'єктів владних повноважень. У порядку адміністративного судочинства не можуть бути оскаржені і переглянуті правові акти Верховної Ради України, Президента України, КМУ, Верховної Ради АРК щодо їх конституційності. Проте у справах щодо оскарження підзаконних правових актів інших суб'єктів владних повноважень адміністративний суд може перевіряти їх відповідність Конституції України, міжнародним договорам, ратифікованим в Україні, законам України та іншим правовим актам вищої юридичної сили.

Вивчення досвіду інших держав у цій сфері свідчить про різноманітні підходи до визначення НПА. Так, у Російській Федерації на державному рівні відсутнє легальне визначення НПА, натомість розроблено проекти Федерального закону «Про нормативно-правові акти Російської Федерації». Водночас окремі суб'єкти РФ вже прийняли акти такого роду (Іркутська, Тверська області та ін.) [24, с. 161-162]. Закон Республіки Білорусь «Про нормативні правові акти Республіки Білорусь» визначає НПА як офіційний документ установленої форми, прийнятий (виданий) в рамках компетенції уповноваженого державного органу (посадової особи) або шляхом референдуму з дотриманням встановленої законодавством Республіки Білорусь процедури, що містить загальнообов’язкові правила поведінки, розраховані на невизначене коло осіб і неодноразове прийняття (ст. 1). Аналогічні положення містяться у ч. 11 ст. 1 Закону Республіки Казахстан «Про нормативні правові акти» [25] та ст. 2 Закону Республіки Молдова «Про нормативні акти Уряду і інших центральних органів» [26]. Одночасно ст. 2 Закону Республіки Молдова «Про адміністративний суд» визначає і поняття адміністративного акта як одностороннього юридичного вираження волі нормативного або індивідуального характеру органу публічної влади у зв’язку з організацією виконання або виконання закону [27].

Необхідно зазначити, що свого часу грунтовна розробка теорії адміністративного акта була здійснена французькими та німецькими вченими [4, с. 47-48]. 
Головними відмінностями їх підходів є те, що у французькому адміністративному праві адміністративний акт може бути нормативним і індивідуальним, а у німецькому адміністративному праві адміністративний акт і видання норм права вважається різними формами виконання управлінських дій. У німецькому адміністративному праві законодавець вважає адміністративним актом кожне розпорядження, рішення або іншу владну дію, які уособлюють в собі конкретно-індивідуальне регулювання (на відміну від правових норм (НПА), що встановлюють абстрактно-загальне регулювання).

Так, відповідно до п. 35 Закону про адміністративне провадження Німеччини адміністративним актом є будь-яке владне діяння адміністративного органу, направлене на врегулювання одиничного випадку у галузі публічного права і такого, що має прямі правові наслідки зовнішнього характеру та є логічним завершенням відповідної процедури, конкретизує застосування законодавчої норми, реалізує виконавчу функцію, будучи виконавчим документом, направленим на захист (порушеного) права. Адміністративний акт направлений на визначене коло осіб або розрахований на використання невизначеним колом осіб (суспільством), і правові наслідки, викликані дією владного волевиявлення, не обмежуються суб'єктами публічної адміністрації [28, с. 37]. Крім того, доктрина про джерела права Німеччини розглядає як нормативний правовий акт також постанови, що є нормами права і застосовуються як адміністративні інструменти у тих випадках, коли адміністрація при виконанні формальних законів повинна і має намір однаково регламентувати не лише одиничні правовідносини, а й розв'язувати значне, таке, що не підлягає точному визначенню, число аналогічних справ [29, с. 22].

Зазначені вище підходи до НПА сприйняті деякими країнами, зокрема Естонією. Так, Адміністративно-процедурний кодекс Естонської Республіки в ст. 4 встановлює, що адміністративними актами, які можуть бути оскаржені або опротестовані в адміністративному суді, є правові акти виконуючих публічно-правові адміністративні функції установ, посадових осіб і інших осіб, видані для врегулювання приватних випадків в приватноправових відносинах. Цікаво, що цією статтею також встановлено, що адміністративним актом за змістом зазначеного кодексу є також адміністративний договір, який регулює публічно-правові відносини [30]. Закон «Про адміністративне провадження» Республіки Естонія в ст. 51 визначає адміністративний акт як правовий акт, виданий адміністративним органом під час виконання адміністративних задач у публічно-правових відносинах для регулювання окремого випадку і направлений на створення, зміну або припинення прав або обов язків особи.

Підсумовуючи викладене, зазначимо, що НПА як складне комплексне правове явище може одночасно розглядатися як документ, акт, рішення, дія, припис, волевиявлення, форма та джерело управління. Для подальшого ж удосконалення підходів до розуміння досліджуваного нами явища вважаємо слушним виділити узагальнюючі ознаки НПА як письмового документа, який містить норми-правила поведінки широкого спрямування. 
Список літератури: 1. Поляков А. В. Общая теория права: Феноменолого-коммуникативный подход : курс лекций / А. В. Поляков. - СПб. : Юрид. центр Пресс, 2003. - 845 с. 2. Битяк Ю. П. Наука адміністративного права України : поняття, предмет, методологія дослідження (адміністративних) правовідносин / Ю. П. Битяк // Право України. - 2013. № 12. - С. 122-140. 3. Малько А. В. Теория правових актов : необходимость и пути создания / А. В. Малько, Я. В. Гайворонская // Государство и право. - 2012. - № 2. - С. 15-24. 4. Старилов Ю. Н. Административное право: в 2 ч. / Ю. Н. Старилов. - Воронеж: Изд-во Воронеж. гос. ун-та, 2001. - Ч. 2. Кн. вторая. - 2001. - 432 с. 5. Васильев Р. Ф. Акты управления: монография / Р. Ф. Васильев. - М. : МГУ, 1987. - 140 с. 6. Косович В. До визначення поняття «нормативно-правовий акт» : практична необхідність і теоретична можливість уточнення / В. Косович // Право України. - 2012. - № 9. - С. 274-280. 7. Курс адміністративного права України : підручник / [В. К. Колпаков, О. В. Кузьменко, І. Д. Пастух, В. Д. Сущенко та ін.]. - 2-ге вид., перероб. і допов. - К. : Юрінком Інтер, 2013. - 872 с. 8. Гуржій Т. О. Адміністративне право України: навч. посіб. / Т. О. Гуржій. - К. : КНТ, Х. : Бурун і К, 2011. - 680 с. 9. Універсальний словник української мови [уклад. 3. Й. Куньч]. - Тернопіль: Навчальна книга - Богдан, 2005. 848 с. 10. Харитонова О. І. Адміністративно-правові відносини (проблеми теоріі): монографія / О. І. Харитонова. - Одеса : Юрид. літ., 2004. - 328 с. 11. Адміністративне право : підручник / [Ю. П. Битяк (кер. авт. кол.), Д. В. Лученко, В. М. Гаращук, В. В. Богуцький та ін.]; за заг. ред. Ю. П. Битяка, В. М. Гаращука, В. В. Зуй. - [2-ге вид., переробл. та допов]. - Х.: Право, 2012. 656 с. 12. Артикул 12, 13 поділу 2 Адміністративний кодекс УСРР, затверджений постановою Всеукраїнського Центрального Виконавчого Комітету від 12 жовтня 1927 р. [Електронний pecypc]. - 2014. - Режим доступу: http://search.ligazakon.ua/__doc2.nsf/link1/KP270014.html. 13. Антоненко С. А. Електронні фонди нормативно-правової інформації парламенту України : (прав., організац. та технол. аспекти) : монографія / С. А. Антоненко ; за заг. ред. М. Я. Швеця. К. : Ред. журн. «Право України» ; Х. : Право, 2013. - 308 с. - (Наук. зб. «Академічні правові дослідження». Дод. до юрид. журн. «Право України»; вип. 32). 14. Про нормативно-правові акти: проект Закону України № 7901 від 01.12.2010 р. [Електронний ресурс]. - 2014. - Режим доступу: http://w1.c1.rada.gov.ua/pls/zweb2/webproc4_2?pf3516=7409\&skl=7. 15. Проекти Адміністративно-процедурних кодексів [Електронний ресурс]. - 2014. - Режим доступу : http:// w1.c1.rada.gov.ua/pls/zweb2/webproc4_2?id=\&pf3516=2789\&skl=7, http://w1.c1.rada.gov.ua/pls/ zweb2/webproc4_1?pf3511=44893. 16. Про Кабінет Міністрів України : Закон України від 16.05.2008 р., № 279-VI // Офіц. вісн. През. Укр. від 17.05.2008 р., № 17 - С. 3. - Ст. 557. 17. Про затвердження Регламенту Кабінету Міністрів України: Постанова Кабінету Міністрів України від 18.07.2007р., № 950 // Урядовий кур’єр від 03.08.2007 р., № 138. 18. Про центральні органи виконавчої влади : Закон України від 17.03.2011 р., № 3166-VI // Голос України від 09.04.2011 р., № 65. 19. Про вдосконалення порядку державної реєстрації нормативно-правових актів у Міністерстві юстиції України та скасування рішення про державну реєстрацію нормативно-правових актів : Наказ Міністерства юстиції України від 12.04.2005 р., № 34/5 // Офіційний вісник України від 29.04.2005 р., № 15. - С. 312. - Ст. 799. - Код акта 32062/2005. 20. Рішення Конституційного Суду України у справі за конституційним поданням Харківської міської ради щодо офіційного тлумачення положень частини другої статті 19, статті 144 Конституції України, статті 25, частини чотирнадцятої статті 46, частин першої, десятої статті 59 Закону України «Про місцеве самоврядування в Україні» (справа про скасування актів органів місцевого самоврядування) від 16.04.2009 р., № 7-рп/2009 // Офіційний вісник України від 08.05.2009 р., № 32. - С. 77. - Ст. 1084. - Код акта 46467/2009. 21. Рішення Коституційного Суду України у справі за конституційним поданням 139 народних депутатів України щодо відповідності Конституції України (конституційності) указів Президії Верховної Ради України «Про тимчасове припинення діяльності Компартії України» $\mathrm{i}$ «ро заборону діяльності Компартії України» (справа про укази Президії Верховної Ради України щодо Компартії України, зареєстрованої 22 липня 1991 року) від 27.12.2001 р., № 20-рп/2001 // Офіційний вісник України від 18.01.2002 р., № 1. - С. 148. - Ст. 28. - Код акта 21067/2002. 22. Рішення Конституційного 
Суду України у справі щодо відповідності Конституції України (конституційності) положення підпункту 2 пункту 3 розділу IV Закону України «Про Конституційний Суд України» стосовно правових актів органів Верховної Ради України від 23.06.1997 р., № 2-зп // Офіційний вісник України. - 1997. - № 27. - С. 155. - Код акта 1778/1997. 23. Про окремі питання юрисдикції адміністративних судів : Постанова Пленуму ВАСУ від 20.05.2013 р., № 8. 24. Риндюк В. І. Проблеми законодавчої техніки в Україні : теорія та практика : монографія / В. І. Риндюк ; відп. ред. О. І. Ющик. - К.: Юридична думка, 2012. - 272 с. 25. О нормативных правовых актах : Закон Республики Казахстан. - Алматы: ЮРИСТ, 2011. - 28 с. 26. Про нормативні акти Уряду і інших центральних органів : Закон Республіки Молдова № 317 від 18.07.2003 р. [Електронний pecypc]. - 2014. - Режим доступу : http://www.law-moldova.com/law_moldova_rus.html. 27. Про адміністративний суд : Закон Республіки Молдова № 793-XIV від 10.02 .2000 р. [Електронний pecypc]. - 2014. - Режим доступу: http://www.law-moldova.com/laws/rus/administrativnomsude-ru.txt. 28. Административно-процесуальное право Германии = Verwaltungs-rechtsschutz in Deutschland : Закон об административном производстве ; Закон об административных судах ; Закон об административных расходах ; Закон о доставке административных решений : [пер. с нем.] ; введ., сост. В. Бергманн. - [2-е изд., перераб.]. - М. : Инфотропик Медиа, 2013. - 288 с. 29. Введение к российскому изданию. Административно-процессуальное право Германии = Verwaltungs-rechtsschutz in Deutschland : Закон об административном производстве ; Закон об административных судах ; Закон об административных расходах ; Закон о доставке административных решений ; [пер. с нем.] ; введ., сост. В. Бергманн. - [2-е изд., перераб.]. - М. : Инфотропик Медиа, 2013. - 288 с. 30. Адміністративно-процедурний кодекс від 11 березня 1999 р., № 570 Естонської Республіки [Електронний ресурс]. - 2014. - Режим доступу : http://estonia. news-city.info/docs/sistemse/dok_iegwei/index.htm.

\section{ОБ ОПРЕАЕАЕНИИ НОРМАТИВНО-ПРАВОВОГО АКТА В ААМИНИСТРАТИВНОМ ПРАВЕ \\ Борбунюк А. А.}

Раскрыто понятийно-категориальный аппарат понятия нормативно-правового акта, основные теоретико-методологические подходы к проблеме определения нормативно-правового акта. Выделено признаки нормативно-правового акта как письменного документа, содержащего нормы-правила поведения общего направления.

Ключевые слова: нормативно-правовой акт, теория нормативно-правового акта, определение нормативно-правового акта, административный акт, правовой акт.

\section{TO DETERMINE THE ADMINISTRATIVE ACT Borbuniuk 0. 0.}

Reveals the notion administrative act, the main theoretical and methodological approaches to the definition of an administrative act. Highlight a sign of an administrative act as a written document containes the rules of conduct of general direction.

Key words: administrative act, the theory of the administrative act, the definition of an administrative act, legal act.

Надійшла до редакції 20.02.2014 p. 